\title{
The Sustainable Ethnicity of old Founded Streets of the Lahore - A case study of Walled city
}

\author{
A.M.Malik ${ }^{1}$, M. Y. Awan ${ }^{1}$, M.Rashid $^{1}$, S.Aziz $^{2}$
}

\begin{abstract}
- the streets have a natural culture to connect people with one another and to places and assist them to commune from places to places and similar pattern repeats itself. This continues from micro to macro level including different neighborhoods to cities and much more thus staging as means for communal gatherings also acting like a small cosmos or center for cultural practices. The streets in the old founded areas of cities are treated as places that connect and strengthen the society. This research paper focuses on studying the character and distinctiveness thus the sustainable character of the streets taking up an old street culture that is the walled city of Lahore as to how it evolved and what its strength is. This research was supported by literature study and speculation. The study reveals that the streets of walled city Lahore shares countless stories of its magnificent past and gives a clue regarding the historic street culture that has sustained itself yet some neighborhoods have been revitalized keeping its original context thus connecting to the street patterns of old founded Lahore with the new parts of the city now. This study depicts that the streets of old founded areas of Lahore have evolved at a slow pace yet preserving most of its historic structure thus keeping its sustainability setting up some ground rules for the generation next.
\end{abstract}

Keywords-Mughal architecture; Cultural heritage; Monument; Archaeology; decay; deterioration; destruction; restoration; neglect; maintenance; façade.

\section{INTRODUCTION}

Since the beginning of Lahore saw the instability and serenity stations, including all the stories of being a princely state and was also plundered during the Lahore insurrections still managed to stay under the spotlight for various periods of time. It's acclaimed as a city that carries many stories for authors and artistes, was very popular during the $1500 \mathrm{AD}$ when the Mughal Empire recognized its main capital here and King Akbar built a Fortified wall thirty feet around the city with twelve different doors initially with addition of a door "Mori" which was made during the British era. The fortified city itself is a small world within this great city of Lahore not only because of its glorious architecture but its people as well as one can find old habits and values here and the people who live

Manuscript received Feb. $10^{\text {th }}, 2017$. This work was supported by School of Architecture and Planning, University of Management and Technology, Lahore, Pakistan.

A.M. Malik (Assistant Professor) is with the School of Architecture and Planning, University of Management and Technology, Lahore, Pakistan.

M. Rashid (Assistant Professor) (Corresponding Author) is with the School of Architecture and Planning, University of Management and Technology, Lahore, Pakistan. in their Ancestral homes called havelis or mansions. The City lies in an old hill northwest of Lahore which dashes its history which is several years of 1000. Latif in his book claims to know the exact date of its foundation is impossible, but concludes that Lahore was an important middle of the seventh century city. It is one of the most vibrant cultural centers of the world known as one of the fortified cities with natural settlements with the narrowest streets in the world that connects all mohallas, katras and kochas. The question is what makes it unique and different from the restored walled city. Vivid memories of my childhood so far might perhaps be the whole concept of the fortified city, its streets, its mohalas and kochas as it's very inspiring. These streets have experienced the historical contributions of the Afghans, Tughluqs, Lodhis, Hindus, Moguls, Sikhs and British. Fragments of these times are still in every street corner and corner of the walled city which makes her a city of wonder and magnificence.

Now the paths or the streets are used as spaces of connection, which allows the movement of goods and people. They also act as places of social gathering, informal gathering of people, where children play and emulate others and learn from them; Where the culture of the communities take root and where they carry out the integrated services. The streets are also a way of life segment by history. The streets also mean a segment of life in the form of history. They serve as a link to our past. The streets of the walled city have a character and a much stronger attribute that has achieved for so many years and still exists. Not only was this reinforced by the addition of more global proposals such as the culinary culture of the streets or other arts schools. In accordance with the principles of urban planning, the hierarchy of streets and facilities are the first priority. The streets allow us to travel from place to place, to shopping, to eating and to participating in social interaction with others. These streets are the public and private area with other parts of the city.

The French Revolution of the seventeenth century led to the development of a new and even more techno physical models of the city replaces the old systems with the new security because they are not more effective. Defensive systems are a top priority, while planning for any urban planning. The twentieth century brought changes in street habits of use and design. The communication environment and the rich culture of the streets were replaced by the efficiency of the means which made them more efficient. Some combined roads served the purpose of streets and roads, while the others were only for vehicles. A negative impression has continued supremacy of pedestrian privileges as one of the characteristics of the street was lost in 
the process. It also ended in the introduction of vocabulary off the street as a road, highway, mall, avenue, boulevard, road and walk all used interchangeably. The main task was to study the difference between a "street" and a "place" that was ranked by the quality of life on the street and the services offered to its users, especially pedestrians. The growing trends of the street today use vehicle control roads in cities which have led to social and physical degeneration.

The fortified city of Lahore was developed at a slow pace, keeping its old structures built, rich traditions and cultures glorious, saving them for generations that were not created either by a man or for a period. Urban sprawl was as an organic course greeted de preoccupations of ordinary human intellects. While studying the character of streets that are usually right at short distances but also mostly winding and twisting ensuring safety and discretion with the element of surprise of what might come after? The town's layout makes a mesh consisting of social and cultural activities with public and private places to each other as a mixture, it moves through intricate ways that are often effective for only pedestrians. Building with most soils are sufficiently effective to maintain the temperature by providing shade to most hours protecting the streets contracted rays of the extreme sun with less open space for movement along the narrow streets and surrounding structures Are typically used for shops on the ground floor with family residences on the upper floors with a flat roof or mumtis. These roofs have been used for sleeping purposes in summer, but also social exchange throughout the year today several times like Basant etc.

\section{RESOURCES AND APPROACHES}

The pockets of the neighborhood around the 13-door walls are more or less the same but with differences in some levels so that the material for this study in the walled city was collected from primary and secondary sources of historical literature that was checked over scrutinizing the streets of the walled city. Many visits were made for review by detailed observation. Thus, the collected material was analyzed with reference to its urban composition of the horizontal networks.

\section{RESULTS AND DISCUSSIONS}

Through careful study of the results of academic research reveal that the streets here have been used social places primarily informal for locals as a place to act as a place where he directs human desires into their natural, cultural and historical resources. For public places equally important social values users like any other inclusion or link values. Similarly, Walled City Street acts as a place where the landscape offers users according to their cultural and natural context. The ladies of families often stand in jharokas doors or balconies or sit on the steps of the entrance to discuss as previously mentioned that the street design offers intimacy and the shade of the burning sun.

The streets have a Guzars descending from the Mohallas hierarchy to Gallis and then to the Galli band is the blind end.
Before the industrial revolution, people used oxen, wagons, horses, camels and oxen for mobility purposes.

There are some spaces in the horizontal layout of the walled city that adopts kindness among residents known as Katrah an outdoor life or a podium that has privacy because of the one-eyed end of the street as the band of Galli used for social interactions also known as cul-de sac giving privately attenuated aliens to enter here. Apart from these there are other characteristics that are found in the walled city of Lahore these factors are discussed in Detail below identifies the street forces of the walled city and they even make it immortal and stand out in the crowd, then other contemporary streets of Lahore have founded other areas:

\section{1: Potency}

Any street in the city should be flexible enough to allow efficient use for everyone, both drivers and the pedestrians. Places with multidisciplinary features offer more possibilities to its users than they are designed to limit them to a minimum function. This quality of environment is known as its strength or robustness. This quality of street of the city is usually obtained by the diversified use of this place. No isolation of activities in the streets of the fortified city, either residential or commercial bazaars. Any function of the street perfect for residential activities do justice also for commercial activities. This type of mixed use includes life and vitality in the streets of the walled city. Robust mix of people of all kinds, ages with activities and, therefore, on the basis improves the chances of sociability among people in this particular area, that this trade is less in those of contemporary areas, as they usually do Know not their neighbors or their professions where the people of the fortified city always know the other with all their family reasons.

\section{2: Self-Sustained Security}

For a new comer these narrow streets look like a labyrinth full of cul-de-sacs- the band gallis where in fact these streets offer a slight clue for buffer spaces that operates as riddles or strains to keep these strangers out. The above mentioned thresholds or buffers are usually in the form of the arches, doorsteps, low stone posts or just the unexpected thinning and curving of the street. Usually the ladies spend their time standing at the doorsteps to keep an eye on their children and other activities happening on the street referring to the 'eye on street' concept by Jane Jacob that she mentioned in her article "Death of the cities". The jhorakas or windows open onto the streets where a neighbor is usually more familiar than a new comer emphasizing on safety as these private spaces open into semi-public places that offers more cordiality and the 'eye on street' by the household themselves thus ends into a natural dog eye watch of the street itself. These streets are beautifully ornamented with balconies, windows, Jharokas with woodwork detail and other architectural features and activities. They also aid in generating a pleasant pedestrian environment. Not just the ladies men or elderly of the household is also found to spend more time sitting at the doorstep or in their house with doors open thus creating a physical link of the house with the public space (the street) that enhances the sense of possession and 
natural surveillance as mentioned by Oscar Newman that: "Windows and doorways, when facing streets, extend the zone of residence' territorial commitments. "This is also understandable as "visual permeability" in the sense that these windows, doorways and balconies all add in the visual permeability between the private and public spaces of any particular street. This feature makes a feeling of protection among the users of the street that they are not alone in the public space thus offers more comfort and ease by eliminating the feeling of being disconnected. All these activities promote walk ability and the makes the pedestrian more secure about the surroundings.

\section{3: Communal Spot}

Lahore's biggest cultural trait includes shopping and is considered to be as ceremonial including inspection, assortment and bargain power that points to an imprudent meet up with the locals or individuals from around. Diners like shops of local foods like halwa puri, lassi or siri payi are employed as the casual assemblies. Alexander also told that "people choose to linger in public spaces where they can enjoy the view towards some feature of interest". Meting other people also are a mannerism in our ethos of our society still found in the walled city streets.

\section{4: Congruence And Inclusion:}

The term "Enclosure" is related to the scope to which these buildings, naturals cape including trees, boundary walls and other elements that defines the urban settlement visually. The feeling for enclosure is improved by the building heights on both sides of streets that in turn directs to cordiality among the users. The streets can be more effective if the planners reduce the width of the roads so the dwellings come practically close enough then it can provoke an urban quality which lifts the spirit of the residents. The skyline and the structures should complement each other rather different in external façade yet integrated with the whole composition. These unites the walled city's urban structure followed by the curvilinear street layout also provides visual closure. These curvilinear streets generate element of surprise as the street proceeds it starts converging into a visually spacious pedestrian places. The streets should be for staying in and not for moving through the way they are today that can be achieved by making a bulge in the center of the public bath and make the ends more narrow so that the path forms an enclosure which is a place to stay and not just to pass through.'

\section{CONCLUSION AND RECOMMENDATION}

A detailed assessment based on thorough studies of the street arrangement of the walled city Lahore tells that for arrangement of the street scheme there has always been a fear for mobility with its communal and psychosomatic effects. The span of the streets provides ways of this a agility whatsoever means for movement were used previously. They were also worried about the communal and self-protective systems for example the concept of cul-de-sac are mostly seen in walled city. Various efforts have been made to relate streets as an abode then just a trail that also consist of an obvious gist in the use and charisma of the street arrangement. Roads should not be confused with streets. The standard of life can be enhanced if these streets having these activities take place are energetic and well designed. The design of the public spaces especially the street influences that can happen for such social activities like spending time on the streets like conversation, shopping and keeping a security check on one another. The suspension of pedestrians on the roads is due to increase in traffic, contamination and noise as a result of it and has results in decrease of social interaction of people of any age group on streets. The idea is to increase awareness about the street conditions of Lahore today and indulge ideas to improve the future. In many areas the streets are at jeopardy for the walkers use due to fast traffic and so it is unsocial and unsafe attribute. Customarily the citizens stay home and move only in their private vehicles that minimizes the street use. Another attribute of the street is its usage as a place of casual gatherings that also includes exchange of dialogues and entertainment. It also fortifies people's social needs to meet one another on daily basis without officially going anyplace.

\section{REFERENCES}

[1] Anita M.Weiss "Challenges for Muslim Women in a Post Modern World", published in "Islam Globalization and Modernity". 2004, pg-111-145

[2] Alexander C. "A Pattern Language - Towns Buildings Construction". New York: Oxford University vol-2, Press, 1997. Pg-123-234

[3] Alexander, C. "A City is Not a Tree", reprint from magazine Design, London: Council of Industrial Design, 1959.

[4] Bently, I. "Responsive Environments: A manual for designers" Architectural Press, 1962. P: 15-19

[5] Broadbent, Geoffrey. "Emerging Concepts in Urban Space Design". New York: E\&FN Spon, 2009. P.123-128

[6] Gibberd, F. "Town Design", Architectural Press. London. (1938), p.181-183

[7] G.J.William. "Making Lahore Modern: Constructing and Imagining a Colonial City". Unity of Minnesota Press, 2007. P. 48-49

[8] Ibid, p.213, 2330.

[9] J. Alan Prive. "Traffic in Towns: A Review of the Buchanan and Crothers Reports"The Town Planning Review, Vol. 28, No.2 (Jan, 1964), pp. 185-191 Liverpool University Press.

[10] J. Jane. "Death and Life of Great American Cities". New York: Random House, 1955.

[11] Krier, R. "Urban Space". London: Academy Edition, 1983

[12] L, Muhammad. "Lahore: Its History, Architectural remains and Antiquities". Lahore: new Imperial Press, 1889. P.35-45

[13] M. Cliff. "Urban Design Street and Square" Burlington: Architectural Press, 1998. P.83-89

[14] Newman. Oscar. "Defensible Space; Crime Prevention through Urban Design”. Macmillan. Pub Co, October 1978.ed-1. P.37-42

(All authors can include biographies with photo at the end of regular papers.)

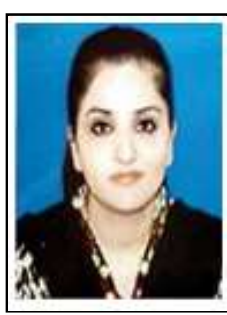

\section{Ayesha Mehmood Malik}

Place: Lahore, Pakistan

A bonafide faculty member and a Ph.D Scholar at University of Management and Technology Lahore.

Masters in Interior Design from National College of Arts, Lahore. (2009)

Bachelors in Architecture from University of Engineering and Technology Lahore. (2005)

She has 10 years of teaching and field experience in the architectural firms and also as a visiting faculty at various institutions mastering in both subjects of architecture and interior designing. 
A distinction holder Ayesha Mehmood Malik has contributed in many universities like National College Of Arts, Lahore, University of Engineering and Technology, Lahore and LSFD, Lahore. She is an executive member of PCATP and IAP, Lahore. Currently working as Assistant Professor in University of Management \& Technology, Lahore, Pakistan. She has conducted several thesis at the bachelor's level in architectural institutes. She is also working as external advisor in various institutes like Lahore College for women university, Lahore. She is ambitious in promoting the research work to a new level.

She carries an amazing academic record and aiming to serve better after completing her Phd. Her areas of interest are Interior Designing, Architectural Conservation and heritage, legislation and Urban Development etc.

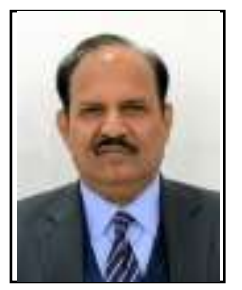

Dr. M.Y. Awan is a Professor and Dean at School of Architecture and Planning, University of Management and Technology, Lahore-Pakistan. He got his Ph.D in Architecture from University of Sheffield, England, United Kingdom.

Dr. Awan has over 40 years of experience in teaching, research and administration. He had earlier served as a Chairman, Coordinator Undergraduate, Director post graduate programs of the Department of Architecture, Chairman Proctorial Board and Advisor Foreign Students at the University of Engineering and Technology, Lahore. $\mathrm{He}$ is $\mathrm{PhD}$ in Architecture from the UK's renowned university of Sheffield. His particular specialization is in Conservation of Architectural and Cultural Heritage. Dr. Awan is a senior member of the Institute of Architects Pakistan (IAP) and served as Honorary Secretary and Vice Chairman of IAP Lahore Chapter. In the year 2010 he played key role as Deputy Convener in organizing the Architecture Students' Jamboree as a part of 14th Asian Congress of Architects (ACA- 14) where students and architects of 17 Asian countries participated. Dr. Awan has supervised more than 500 undergraduate Thesis projects of Bachelor's Degree of Architecture. He has also supervised 31Thesis of Masters of Architecture, 29 at the UET and two at the UMT that were all successfully completed. Number of Dr. Awan's research publications including postgraduate thesis is 50 .

Dr. Awan joined the UMT as Professor and first Chairman of the newly established Department of Architecture and Planning in September 2012. Under his academic leadership the program was granted NOC by the PCATP within shortest time period. Under his academic leadership another program of BS in City and Regional Planning was successfully launched from the Fall Semester 2014. He had also launched postgraduate programs of Master of Architecture (M. Arch), M. Arch. with Specialization in Architectural Conservation, M. Arch. with Specialization in Urban Design and $\mathrm{PhD}$ in Architecture from the Fall Semester 2013.

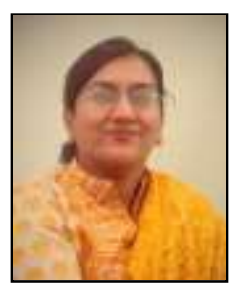

\section{Memoona Rashid}

A Masters Student in the University of Management and Technology Lahore. Bachelors in Architecture from University of Engineering and Technology Lahore. (2006).she is an enthusiastic faculty member of UMT, Lahore.

Worked in Superior University Lahore (August 2014 till June 2015). University of South Asia Lahore (June 2009-June 2014). Currently working as Assistant Professor in University of Management \& Technology, Lahore, Pakistan. Her specialization is in energy efficiency, smart buildings. 